\title{
Influence of Propagation Method on Root Architecture and Other Traits of Young Citrus Rootstock Plants
}

\author{
Ute Albrecht ${ }^{1}$ \\ Southwest Florida Research and Education Center, UF/IFAS, Immokalee, \\ FL 34142
}

Mireia Bordas
Agromillora Florida, Wildwood, FL 34785

Beth Lamb

Phillip Rucks Nursery, Frostproof, FL 33843

Bo Meyering
Southwest Florida Research and Education Center, UF/IFAS, Immokalee,
FL 34142

Kim D. Bowman

U.S. Horticultural Research Laboratory, USDA, ARS, Fort Pierce, FL 34945

Additional index words. seedlings, cuttings, micropropagation, adventitious roots, specific root length

\begin{abstract}
There are generally inadequate supplies of seed for the newest rootstocks to satisfy the growing demand for the propagation material to be used in commercial citrus nurseries. Consequently, rootstock propagation, which is traditionally by seed, now often makes use of alternative methods such as cuttings and tissue culture (TC). Propagation through cuttings and TC will generate a root system that is largely composed of adventitious or lateral roots, compared with seed propagation, which will generally promote the formation of a well-defined taproot. In this study, we compared root architecture and growth of seven different rootstock plants, generated from seed, stem cuttings, or TC, during the early weeks of growth in the greenhouse. Based on total dry biomass, root mass fraction of plants generated from cuttings ranged from $11 \%$ to $16 \%$, and from $16 \%$ to $29 \%$ and $21 \%$ to $30 \%$ for micropropagated plants and seedlings, respectively. Plants propagated through cuttings had the most primary roots (7-10), followed by tissue culture-propagated plants which developed an average of 2-6 primary roots. As expected, plants grown from seeds mostly developed a single and well-defined taproot during the first weeks. The total number of first order lateral roots was highest in the plants propagated as cuttings (108-185) compared with 53-103 and 43-78 for tissue culture-propagated plants and seedlings, respectively. Similarly, specific root length (SRL) was highest in plants derived from cuttings $\left(21-43 \mathrm{~m} \cdot \mathrm{g}^{-1}\right)$ and lowest in plants grown from seed $\left(7-20 \mathrm{~m} \cdot \mathrm{g}^{-1}\right)$. It is suggested that the larger number and length of roots on rootstock plants propagated through vegetative methods may be better suited for resource acquisition as compared with seed propagated plants.
\end{abstract}

Since the arrival of Huanglongbing (HLB), a.k.a. citrus greening in many citrus growing countries worldwide, citrus production continues to decline steadily. In Florida and in most other countries, HLB is associated with the phloem-limited bacterium Candidatus Liberibacter asiaticus (CLas), which is transmitted by the Asian citrus psyllid. Although HLB does not kill a citrus tree quickly, infected trees decline and can

\footnotetext{
Received for publication 17 July 2017. Accepted for publication 8 Sept. 2017.

This paper is based on a presentation given during the Annual Meeting of the Florida State Horticultural Society, which was held 4-6 June 2017, in Tampa, FL.

1Corresponding author. E-mail: ualbrecht@ufl.edu.
}

become unproductive within few years. In addition to controlling vector populations by frequent insecticide applications, growers are trying to mitigate the damaging effects of the disease through nutritional therapies, irrigation management, and other strategies such as use of superior rootstocks.

Although most commercial scion varieties are susceptible to HLB, several rootstock cultivars commercially used in Florida are HLB-tolerant (Albrecht and Bowman, 2011, 2012; Folimonova et al., 2009) and have other positive traits, which allow a grafted citrus tree to remain more productive (Bowman et al., 2016a, 2016b). Rootstock has been an important component of citrus production in Florida at least since the 1860s (Webber et al., 1967; Castle, 2010), not only because they affect the fruit quality and tree size, but also because of their ability to tolerate unfavorable environmental conditions and diseases. Commercial citrus rootstock propagation traditionally occurs through use of nucellar apomictic seed, resulting in genetically identical seedlings used as liners for budding. There is currently a great demand for new and superior rootstocks to replant trees because of loss or declining productivity of trees due to HLB. Unfortunately, there are often inadequate supplies of seed for the newest rootstocks to meet the growing demand for propagation material to be used in commercial nurseries. In addition, some of the newer rootstocks have only few seed or are more prone to producing off-types from zygotic embryos. Consequently, rootstock propagation now has to rely on alternative methods such as the use of cuttings or TC-generated plants. Like plants derived from apomictic seeds, both propagation methods will yield genetically uniform plants that can be used as liners for commercial citrus tree production.

There has been some concern regarding the root structure of plants propagated by vegetative methods. Propagation through cuttings and TC will generate a root system that is largely composed of adventitious or lateral roots, compared with seed propagation, which will promote the formation of a well-defined taproot. Because of their role in water and nutrient uptake, fine roots are the most important part of the root system (Anderson and Ingram, 1993). Trees with a root system consisting of fibrous roots arising from the taproot may, therefore, respond differently to different supplies of nutrients and water than trees with fibrous roots arising from adventitious roots of vegetative origin. Recent studies on HLBaffected citrus have shown that loss of fibrous roots is a direct consequence of infection with CLas, often occurring before disease symptoms become apparent (Johnson et al., 2014). Therefore, root architecture is likely to influence resilience of a commercial citrus tree to HLB and to other biotic or abiotic stressors.

In addition to the propagation method, inherent rootstock characteristics associated with the genotype are expected to have a significant impact on the root structure of a citrus tree. Comparisons of early growth of TC clones and seedlings of Eucalyptus camaldulensis indicated strong morphological differences between genotypes within the species, but no architectural differences, either above- or below-ground, were attributable to micropropagation (Bell et al., 1993). A recent study on vegetative propagation of different citrus rootstocks from stem cuttings showed considerable differences in root length among the different genotypes (Bowman and Albrecht, 2017). Castle and Youtsey (1977) reported considerable differences in the root architectures of nursery-grown Valencia trees on 12 different rootstocks.

It is commonly thought that trees of vegetative origin have an undesirable root system and are prone to wind-induced uprooting because of the absence of a taproot. 
However, Asaah et al. (2012) reported that mature African plum (Dacryodes edulis) trees of vegetative origin have welldeveloped primary lateral and deep sinker roots that confer stability. In the heavy flatwood soils on the east coast and southwest Florida citrus-growing regions, taproots generally do not extend beyond a depth of $30-50 \mathrm{~cm}$ (personal observations). With the advent of microirrigation practices, the same can now be observed for commercial citrus trees grown in the well-drained sandy soils on the central growing regions of Florida. Hence, root architecture and anchorage in the upper zone of the soil will be the most critical factor in the susceptibility of citrus trees to lodging or other types of wind-induced damage.

Table 1. Plant material used in the study and duration of growth (weeks) in cone cells. Plants from tissue culture (TC) method B were grown in Ellepots for 8-10 weeks before transfer.

\begin{tabular}{|c|c|c|c|c|}
\hline \multirow[b]{2}{*}{ Rootstock } & \multicolumn{4}{|c|}{ Propagation method } \\
\hline & Seed & Stem cutting & TC (A) & $\mathrm{TC}(\mathrm{B})$ \\
\hline Cleopatra & レ (18) & レ(20) & - & - \\
\hline Swingle & $\boldsymbol{\nu ( 1 6 )}$ & レ(14) & レ(14) & - \\
\hline US-802 & $\boldsymbol{\nu ( 1 0 )}$ & レ(14) & $\boldsymbol{\nu ( 8 )}$ & レ(4) \\
\hline US-812 & $\boldsymbol{\nu ( 1 6 )}$ & レ(14) & レ(14) & - \\
\hline US-897 & V(16) & レ(14) & レ(14) & $\boldsymbol{\nu}(6)$ \\
\hline US-942 & $\boldsymbol{\nu ( 1 6 )}$ & レ(14) & $\boldsymbol{\nu ( 8 )}$ & - \\
\hline$X-639$ & $\boldsymbol{\nu ( 1 6 )}$ & - & レ(14) & レ(4) \\
\hline
\end{tabular}

According to a survey in Florida, most of the citrus nurseries prefer rootstock liners that originate from seed over those that originate from TC (Chaires, 2017). In addition to the anticipated higher costs of plants from vegetative origin, it is expected that rootstock liners from vegetative propagation have an inferior root system compared with liners derived from seed. In this study, we analyzed the root architecture and other plant traits of seven different rootstock genotypes, generated from seed, stem cuttings, and TC, during the first weeks of growth in the greenhouse. The influence of rootstock and propagation type on root structure and biomass distribution is discussed, as well as the possible implications of propagation method for field performance of commercial trees. This is the first part of a larger study intended to continue assessment of the same trees over several years under field conditions, and to identify what differences in field performance, if any, will be associated with type of propagation method used for the rootstock.

\section{Materials and Methods}

Rootstock genotypes. Seven commercially important citrus rootstocks were used: 'X-639' ['Cleopatra' mandarin (C. reticulata L. Blanco) $\times$ trifoliate orange (Poncirus trifoliata L. Raf)], 'Swingle' citrumelo (Citrus paradisi Macf. $\times P$. trifoliata), and 'Cleopatra' mandarin, which have had

Table 2. Biomass distribution of seven different rootstocks propagated by seed, stem cuttings, and tissue culture (TC).

\begin{tabular}{|c|c|c|c|c|c|}
\hline Rootstock & Seed & Stem cutting & $\mathrm{TC}(\mathrm{A})$ & $\mathrm{TC}(\mathrm{B})$ & $P$ value \\
\hline \multicolumn{6}{|c|}{ Total plant dry weight $(\mathrm{g})$} \\
\hline Cleopatra & $13.8 \mathrm{a}$ & $13.0 \mathrm{a}$ & - & - & 0.4234 \\
\hline US-802 & $9.4 \mathrm{a}$ & $8.8 \mathrm{a}$ & $8.9 \mathrm{a}$ & $11.0 \mathrm{a}$ & 0.2211 \\
\hline US-812 & $9.0 \mathrm{a}$ & $7.8 \mathrm{a}$ & $8.1 \mathrm{a}$ & - & 0.4920 \\
\hline US-897 & $9.1 \mathrm{a}$ & $9.0 \mathrm{a}$ & $7.4 \mathrm{a}$ & $10.1 \mathrm{a}$ & 0.0901 \\
\hline US-942 & $9.3 \mathrm{a}$ & $7.3 \mathrm{~b}$ & $7.5 \mathrm{~b}$ & - & 0.0013 \\
\hline Swingle & $17.1 \mathrm{a}$ & $10.4 \mathrm{c}$ & $13.3 \mathrm{~b}$ & - & $<0.0001$ \\
\hline$X-639$ & $8.6 \mathrm{~b}$ & - & $7.8 \mathrm{~b}$ & $16.7 \mathrm{a}$ & $<0.0001$ \\
\hline \multicolumn{6}{|c|}{ Root mass fraction (\%) } \\
\hline Cleopatra & $25.5 \mathrm{a}$ & $16.3 \mathrm{~b}$ & - & - & $<0.0001$ \\
\hline US-802 & $21.2 \mathrm{a}$ & $13.3 \mathrm{c}$ & $18.6 \mathrm{ab}$ & $18.6 \mathrm{ab}$ & 0.0133 \\
\hline US-812 & $29.3 \mathrm{a}$ & $13.0 \mathrm{~b}$ & $19.6 \mathrm{~b}$ & - & 0.0002 \\
\hline US-897 & $24.1 \mathrm{~b}$ & $10.9 \mathrm{~d}$ & $17.0 \mathrm{c}$ & $28.5 \mathrm{a}$ & $<0.0001$ \\
\hline US-942 & $23.9 \mathrm{a}$ & $10.7 \mathrm{c}$ & $16.2 \mathrm{~b}$ & - & $<0.0001$ \\
\hline Swingle & $29.9 \mathrm{a}$ & $12.7 \mathrm{c}$ & $22.9 \mathrm{~b}$ & - & 0.0001 \\
\hline $\mathrm{X}-639$ & $21.1 \mathrm{~b}$ & - & $14.0 \mathrm{c}$ & $27.6 \mathrm{a}$ & $<0.0001$ \\
\hline \multicolumn{6}{|c|}{ Stem mass fraction (\%) } \\
\hline Cleopatra & $30.0 \mathrm{a}$ & $26.4 \mathrm{~b}$ & - & - & 0.0336 \\
\hline US-802 & $29.2 \mathrm{bc}$ & $34.6 \mathrm{a}$ & $26.9 \mathrm{c}$ & $31.7 \mathrm{ab}$ & $<0.0001$ \\
\hline US-812 & $33.6 \mathrm{a}$ & $36.7 \mathrm{a}$ & $36.5 \mathrm{a}$ & - & 0.1093 \\
\hline US-897 & $34.2 \mathrm{a}$ & $37.4 \mathrm{a}$ & $33.8 \mathrm{a}$ & $34.8 \mathrm{a}$ & 0.0525 \\
\hline US-942 & $33.5 \mathrm{a}$ & $33.8 \mathrm{a}$ & $32.4 \mathrm{a}$ & - & 0.5250 \\
\hline Swingle & $29.4 \mathrm{a}$ & $32.1 \mathrm{a}$ & $28.1 \mathrm{a}$ & - & 0.0970 \\
\hline $\mathrm{X}-639$ & $31.1 \mathrm{~b}$ & - & $32.0 \mathrm{ab}$ & $36.3 \mathrm{a}$ & 0.0115 \\
\hline \multicolumn{6}{|c|}{ Leaf mass fraction (\%) } \\
\hline Cleopatra & $44.4 \mathrm{~b}$ & $57.3 \mathrm{a}$ & - & & $<0.0001$ \\
\hline US-802 & $49.6 \mathrm{a}$ & $51.7 \mathrm{a}$ & $54.5 \mathrm{a}$ & $49.8 \mathrm{a}$ & 0.0725 \\
\hline US-812 & $37.0 \mathrm{~b}$ & $50.3 \mathrm{a}$ & $43.9 \mathrm{ab}$ & - & 0.0009 \\
\hline US-897 & $41.7 b$ & $51.7 \mathrm{a}$ & $49.2 \mathrm{a}$ & $36.7 \mathrm{c}$ & $<0.0001$ \\
\hline US-942 & $42.6 \mathrm{c}$ & $55.6 \mathrm{a}$ & $51.4 \mathrm{~b}$ & - & $<0.0001$ \\
\hline Swingle & $40.7 \mathrm{c}$ & $55.2 \mathrm{a}$ & $49.0 \mathrm{~b}$ & - & $<0.0001$ \\
\hline $\mathrm{X}-639$ & $47.8 \mathrm{~b}$ & - & $54.0 \mathrm{a}$ & $36.1 \mathrm{c}$ & $<0.0001$ \\
\hline
\end{tabular}

Different letters within rows for each rootstock indicate significant differences according to Tukey's HSD test or Dunn's multiple comparison test $(P<0.05)$. historical commercial use worldwide, and 'US-802' ['Siamese' pummelo (C. grandis Osbeck) $\times$ 'Gotha Road' trifoliate orange $(P$. trifoliate)], 'US-812' ['Sunki' mandarin ( $C$. reticulata) $\times$ 'Benecke' trifoliate orange], 'US-897' ['Cleopatra' mandarin $\times$ 'Flying Dragon' trifoliate orange $(P$. trifoliata $)]$, and 'US-942' ('Sunki' mandarin $\times$ 'Flying Dragon' trifoliate orange), four new hybrid rootstocks released by USDA that have gained major commercial importance in Florida (Bowman et al., 2016a, 2016b). Because of the limitations of source material and other complications, it was not possible to generate plants from all rootstocks with all propagation methods. The plant material used in this study is summarized in Table 1.

Seedlings. Fruit were collected from 15- to 30-year-old rootstock seed source trees located at the Whitmore Foundation Farm, Leesburg, FL, in Dec. 2015. Fruit were disinfected for $10 \mathrm{~min}$ in a $1 \%$ sodium hypochloride solution (Chlorox) containing $0.01 \%$ Tween 20 (Sigma). After rinsing the fruit three times with tap water, seeds were extracted and incubated overnight in 0.15 units $/ \mathrm{mL}$ pectinase solution. Seeds were rinsed with tap water, immersed in a $1 \%$ 8-hydroxyquinoline sulfate solution for $30 \mathrm{~min}$, dried, and stored at $4{ }^{\circ} \mathrm{C}$ until use. Seeds were sown into premoistened soilless potting mix (Pro Mix BX; Premier Horticulture, Inc., Quakertown, PA) in June 2016, using racks of $3.8 \mathrm{~cm} \times 21 \mathrm{~cm}$ cone cells (Cone-tainers; Stuewe and Sons, Tangent, OR). After germination, plants were irrigated as needed and fertilized biweekly using a water-soluble fertilizer $(20 \mathrm{~N}-10 \mathrm{P}-$ 20K; Peters Professional, The Scotts Company, Marysville, $\mathrm{OH}$ ) at a rate of $400 \mathrm{mg}$ per liter N. Insecticides were applied as needed. Any off-types arising from zygotic embryos were discarded.

Cuttings. One- to two-year-old plants derived from nucellar seed of each cultivar and maintained in the U.S. Horticultural Research Laboratory (USHRL) greenhouses were used as a source of shoots for the cuttings. Single node cuttings (average length $2.5 \mathrm{~cm}$ ) were taken in April 2016 from woody sections of 2- to 5-month-old branches leaving the leaf attached to each node, but trimming to reduce the leaf size to about $20 \%$ to 30 . The basal end of each cutting was dipped in a commercial rooting powder (Hormodin 2; E.C. Geiger, Inc., Harleysville, PA) containing $0.3 \%$ indole-3-butyric acid, and immediately inserted into $3.8 \mathrm{~cm} \times 21 \mathrm{~cm}$ cone cells (Cone-tainers; Stuewe and Sons, Tangent, OR) containing pre-moistened soilless potting mix (Pro Mix BX; Premier Horticulture, Inc., Quakertown, PA). Cones were placed on a mist bench, and misting was applied for a duration of 6 weeks as described in Bowman and Albrecht (2017). The shadecloth on the greenhouse was closed from 9:00 $\mathrm{AM}$ to 6:00 PM daily during the same time period. During the fifth week, the plants received a liquid fertilizer application of water-soluble fertilizer $(20 \mathrm{~N}-10 \mathrm{P}-20 \mathrm{~K}$; Peters Professional, The Scotts Company, Marysville, $\mathrm{OH}$ ) at a rate of $400 \mathrm{mg}$ per liter $\mathrm{N}$. 
Plants received another liquid fertilizer application after 6 weeks that included chelated iron (Sequestrene $138 \mathrm{Fe}$; Ciba-Geigy Corp., Greensboro, NC). At the beginning of the seventh week, the shadecloth was left open continuously and plant care was continued in the same manner described for seedlings.

$T C-$ method A. Seeds from fruit collected from foundation-derived trees were used as the source of explants for in vitro regeneration. Budwood for the seed trees was obtained from the Bureau of Citrus Budwood Registration (Florida Department of Agriculture and Consumer Services) citrus germplasm collection in Chiefland, FL.

Culture initiation: Seeds were extracted from fruit. The seedcoats were removed and embryos were sanitized using a $1.5 \%$ solution of sodium hypochlorite, followed by three rinses in sterile distilled water. Selected nucellar embryos were placed into clear polypropylene $16 \mathrm{oz}$. (473 mL) deli containers containing Murashige and Skoog (MS) agar nutrient medium (Murashige and Skoog, 1962) without added growth regulators.

Multiplication of Cultures: Multiple shoot clusters were produced by alternating between media containing MS medium with $1.0 \mathrm{mg} \cdot \mathrm{L}^{-1}$ benzyladenine, $0.5 \mathrm{mg} \cdot \mathrm{L}^{-1}$ kinetin, and $0.5 \mathrm{mg} \cdot \mathrm{L}^{-1}$ naphthalene acetic acid (NAA) (Bowman et al., 1997), and MS medium or EXS-III basal medium (PhytoTechnology Laboratories, Lenexa, KS) with no added growth regulators. Multiple shoot clusters were divided and placed in new media on a cycle of about 5 weeks. Elongated shoots suitable for rooting were produced by serial transfers on hormone-free medium.

Rooting of shoots and transfer to soil: Single shoots were obtained by removing sections with at least four nodes and placing them on MS basal medium containing 2.0 $\mathrm{mg} \cdot \mathrm{L}^{-1}$ (NAA) and $1 \mathrm{~g} \cdot \mathrm{L}^{-1}$ active charcoal. After rooting for a period of about 6 weeks, plants were transferred from the commercial TC facility to the USHRL facilities in Fort Pierce, FL. At USHRL, plantlets were removed from the medium, roots were trimmed to 3 $6 \mathrm{~cm}$ length, and placed into $3.8 \mathrm{~cm} \times 21 \mathrm{~cm}$ cone cells containing pre-moistened soilless potting mix (Pro Mix BX). Plants were kept in high humidity in a plant growth chamber (EGC Model M36; Environmental Growth Chambers, Chagrin Falls, OH) with $16 \mathrm{~h} / 24 \mathrm{~h}$ lighting at $200 \mu \mathrm{mol} \cdot \mathrm{m}^{-2} \cdot \mathrm{s}^{-1}$, and humidity was gradually reduced over 3-4 weeks, which allowed plants to acclimate to ambient greenhouse conditions. Plants were then transferred to the greenhouse and maintained in the USHRL greenhouses as described for seedlings.

$T C$-method B. Buds from certified disease-free budwood from the Bureau of Citrus Budwood Registration citrus germplasm collection in Chiefland, FL, was used as the source of explants for in vitro regeneration.

Culture initiation: Young apical shoots were collected from foundation trees in early spring. The plant material was pre-washed with alcohol and disinfected by immersion in a $1.5 \%$ solution of sodium hypochlorite, followed by three washes with sterile distilled water.

Multiplication of Cultures: After disinfection, the buds were cultured in test tubes containing MS-based agar nutrient medium (Agromillora, composition proprietary). Cultures were maintained in a growth room under controlled conditions at a temperature of 24 to $26{ }^{\circ} \mathrm{C}$ and a $16 \mathrm{~h}$ light $/ 8 \mathrm{~h}$ darkness photoperiod. In the multiplication phase, buds were transferred to jars and subcultured every 2 weeks to fresh nutrient medium. After a number of cycles, depending on the number of plants to be produced, explants were transferred to the next phase in which the shoot elongation was promoted. In the elongation phase, cultures were maintained in the growth room under the same conditions as described previously for $8-10 \mathrm{~d}$ until they reached a height of $6-8 \mathrm{~cm}$.

Rooting of shoots and transfer to soil: Elongated plants were individualized by cutting the base, planted in $3.8 \times 4.4 \mathrm{~cm}$ paper-pots (Ellepots) containing a mix of peat (Pelemix, Las Salinas, Spain) and coconut fiber (Klasmann-Deilmann, Geeste,
Germany), and transferred to misting tunnels inside the greenhouse for acclimatization. Under these conditions, the plants developed a root system within 2-3 weeks and hardened for the growth phase. Rooted plants were moved to growth benches, grown until $18-20 \mathrm{~cm}$ in height (8-10 weeks), and then moved to the USHRL greenhouses in Fort Pierce, FL, where they were transplanted into $3.8 \mathrm{~cm} \times 21 \mathrm{~cm}$ cone cells containing pre-moistened soilless potting mix (Pro Mix BX) and maintained as described for seedlings.

Plant assessment. To overcome initial differences due to propagation method, plant growth was standardized as best as possible by placing plants in the same potting mix and container and maintaining them under the same greenhouse conditions. Plants were arranged on the greenhouse benches in blocks based on rootstock and propagation method in accordance with standard nursery practices to optimize growth and avoid inhibition of plant growth due to shading and over-irrigation. Six randomly chosen plants from each rootstock/propagation method combination were assessed when they reached a height of $22-25 \mathrm{~cm}$. The plant size was affected by rootstock vigor and propagation method. Consequently, time of

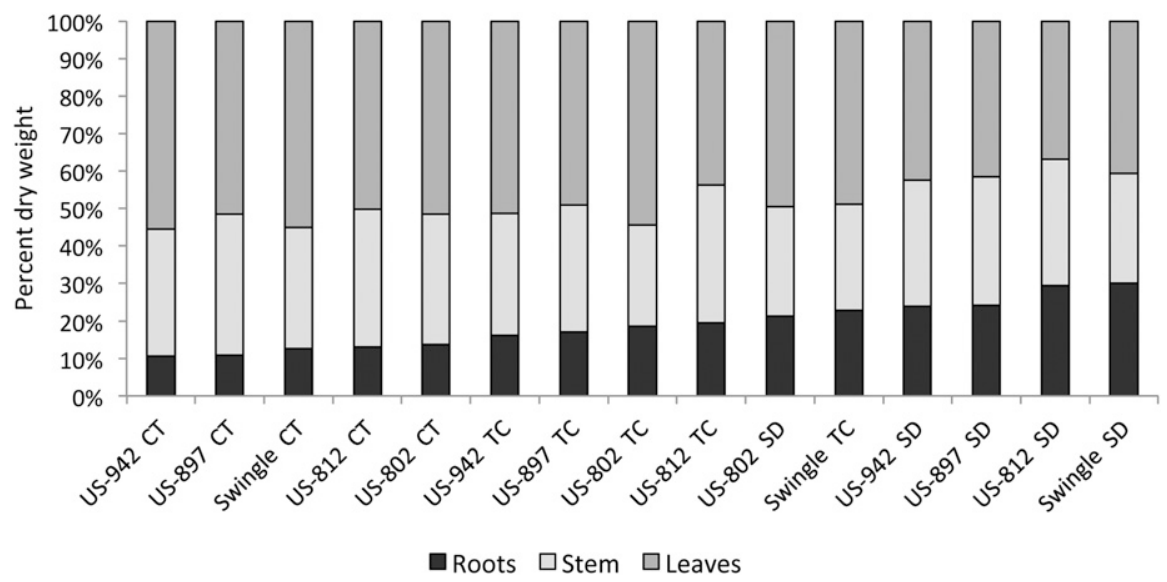

Fig. 1. Biomass distribution of five rootstocks propagated by seed (SD), stem cuttings (CT), or tissue culture (TC). Plants from TC were propagated by method A.

Table 3. Shoot to root dry weight ratio (S/R) and specific leaf area (SLA) of seven different rootstocks propagated by seed, stem cuttings, and tissue culture (TC).

\begin{tabular}{lccccr}
\hline Rootstock & Seed & Stem cutting & TC (A) & TC (B) & $P$ value \\
\hline & & $S / R(g / g)$ & & & 0.0004 \\
Cleopatra & $2.9 \mathrm{~b}$ & $5.2 \mathrm{a}$ & - & - & 0.0211 \\
US-802 & $3.8 \mathrm{~b}$ & $6.5 \mathrm{a}$ & $4.5 \mathrm{ab}$ & $4.9 \mathrm{ab}$ & $<0.0001$ \\
US-812 & $2.6 \mathrm{~b}$ & $6.9 \mathrm{a}$ & $4.2 \mathrm{~b}$ & - & 0.0010 \\
US-897 & $3.2 \mathrm{bc}$ & $8.6 \mathrm{a}$ & $5.1 \mathrm{~b}$ & $2.5 \mathrm{c}$ & 0.0005 \\
US-942 & $3.2 \mathrm{c}$ & $8.5 \mathrm{a}$ & $5.3 \mathrm{~b}$ & - & $<0.0001$ \\
Swingle & $2.4 \mathrm{c}$ & $6.9 \mathrm{a}$ & $3.4 \mathrm{~b}$ & - & 0.0012 \\
X-639 & $3.8 \mathrm{ab}$ & - & $6.6 \mathrm{a}$ & $2.7 \mathrm{~b}$ & \\
& & $S L A\left(\mathrm{~cm}^{2} / g\right)$ & & & 0.0044 \\
Cleopatra & $183.3 \mathrm{~b}$ & $206.2 \mathrm{a}$ & - & - & 0.0008 \\
US-802 & $264.3 \mathrm{a}$ & $273.7 \mathrm{a}$ & $274.3 \mathrm{a}$ & $231.8 \mathrm{~b}$ & 0.6538 \\
US-812 & $277.5 \mathrm{a}$ & $262.0 \mathrm{a}$ & $252.7 \mathrm{a}$ & - & 0.0001 \\
US-897 & $233.7 \mathrm{a}$ & $250.2 \mathrm{a}$ & $242.3 \mathrm{a}$ & $153.9 \mathrm{~b}$ & $<0700$ \\
US-942 & $264.6 \mathrm{a}$ & $281.3 \mathrm{a}$ & $273.6 \mathrm{a}$ & - & $<0.0001$ \\
Swingle & $233.0 \mathrm{~b}$ & $275.7 \mathrm{a}$ & $260.4 \mathrm{a}$ & - & 0.0001 \\
X-639 & $255.8 \mathrm{a}$ & - & $268.6 \mathrm{a}$ & $178.6 \mathrm{~b}$ & $<$
\end{tabular}

Different letters within rows for each rootstock indicate significant differences according to Tukey's HSD test or Dunn's multiple comparison test $(P<0.05)$. 
assessment ranged from 10 to 18 weeks after planting of seeds and from 14-20 weeks after planting of stem cuttings into the cone cells. Tissue culture-generated plants were assessed 8-14 weeks (method A) or 4-6 weeks (method B) after introduction to the cone cells.

For assessment of plant biomass distribution, leaves, stems, and roots were separated from each plant. Leaves from each plant were scanned with a Cannon MG 3620 scanner and leaf area was determined using Assess 2.0 (Lakhdar Lamari, American Phytopathological Society) image analysis software. Roots were cleaned from adhering potting medium, washed, and blotted dry. Plant tissue was dried in an oven at $53{ }^{\circ} \mathrm{C}$ to a constant weight, and dry weights of leaves, stems, and roots were determined. Shoot to root ratio was determined by dividing combined dry weights of stems and leaves by dry weight of roots. Specific leaf area (SLA) was determined as the ratio of leaf area $\left(\mathrm{cm}^{2}\right)$ to leaf dry weight $(\mathrm{g})$.

Before drying, roots from each plant were scanned as described previously. Primary roots [taproot(s) or adventitious roots] and first order lateral roots (defined as lateral roots directly arising from the primary root) of each plant were counted and total root length (TRL) was measured using Assess 2.0 image analysis software. Specific root length was determined as the ratio of root length $(\mathrm{m})$ to dry weight of roots $(\mathrm{g})$.

Analysis of variance (ANOVA) was conducted using Statistica v13 software (Dell Statistica, Tulsa, OK) and main effect means were separated using Tukey's HSD post hoc test. Where assumptions of ANOVA were not met, Kruskal-Wallis ANOVA, followed by multiple comparison of mean ranks, was conducted. Factorial ANOVA was employed for the five rootstock varieties for which plants generated from seed, cuttings, and TC (method A) were available ('US-802', 'US812', 'US-897', 'US-942', and 'Swingle'). The significance threshold was set at 0.05 .

\section{Results}

Biomass distribution. The total dry biomass of plants ranged from $7.3 \mathrm{~g}$ for 'US-942' cuttings to $17.1 \mathrm{~g}$ for 'Swingle' seedlings (Table 2). Total biomass was significantly influenced by propagation method for the rootstocks 'US-942', 'Swingle', and 'X-639'. The percent biomass allocated to roots differed significantly among propagation methods for all seven rootstocks. Except for 'US-897' and 'X-639', root mass fraction was highest in plants grown from seed $(21 \%$ to $30 \%$ ), and lowest in plants grown from cuttings ( $11 \%$ to $16 \%)$. For TC-propagated plants, root mass fraction was $28 \%$ to $29 \%$ for 'X-639' and 'US-897' propagated by method B compared with $14 \%$ to $23 \%$ for the remaining plants. The proportion of biomass allocated to stems differed significantly between plants propagated by different methods for 'Cleopatra', 'US-802', and 'X-639', and ranged from $26 \%$ in 'Cleopatra' cuttings to $37 \%$ in 'US-812' and 'US-897' cuttings. For all rootstocks, except 'US-802', the percentage of biomass allocated to leaves also differed significantly based on the propagation method used. The highest leaf mass fraction was observed for cuttings $(50 \%$ to $57 \%$ ), and the lowest proportion was observed for seedlings $(37 \%$ to $50 \%)$ in all rootstocks, except for 'X-639' for which the lowest proportion of leaf biomass was found for plants derived from TC method B.

Factorial analysis of the rootstock cultivars 'US-802', 'US-812', 'US-897', 'US942', and 'Swingle' revealed a significant interaction of rootstock and propagation method for total biomass $(P=0.0002)$ and for the partitioning of biomass to roots $(P=$ $0.0107)$, stem $(P=0.0233)$, and leaves $(P=$ 0.0010 ). The highest root mass fraction was found for 'Swingle' and 'US-812' seedlings

(29.3\% to $29.9 \%)$ and the lowest was found for 'US-897' cuttings (10.7\%). 'US-897' cuttings had the highest percentage of stem biomass (37.4\%) and 'US-802' from TC method A had the lowest percentage (26.9\%). 'Swingle', 'US-802', 'US-897', and 'US-942' cuttings and 'US-802' and 'US-942' from TC B had the largest leaf mass fraction $(51.4 \%$ to $55.6 \%)$ whereas 'US-812' from seed had the lowest $(37.0 \%)$. Biomass distribution for the five rootstocks and the three propagation methods is presented in Fig. 1. Despite the significant interaction between rootstock and propagation method, there is a clear trend for an increase in the proportion of roots from cuttings to $\mathrm{TC}$-propagated plants to seedlings.

Table 4. Factorial ANOVA of shoot to root dry weight ratio (S/R) and specific leaf area (SLA) of five rootstocks propagated by seed, cutting, and tissue culture (TC) method A.

\begin{tabular}{lcccc}
\hline Effect & Level of factor & $\mathrm{N}$ & $\mathrm{S} / \mathrm{R}(\mathrm{g} / \mathrm{g})$ & $\mathrm{SLA}\left(\mathrm{cm}^{2} \cdot \mathrm{g}^{-1}\right)$ \\
\hline Rootstock & US-942 & 18 & $5.64 \mathrm{a}$ & $273 \mathrm{a}$ \\
& US-897 & 18 & $5.62 \mathrm{a}$ & $242 \mathrm{~b}$ \\
& US-802 & 18 & $4.93 \mathrm{ab}$ & $271 \mathrm{a}$ \\
& US-812 & 18 & $4.58 \mathrm{~b}$ & $264 \mathrm{ab}$ \\
& Swingle & 18 & $4.22 \mathrm{~b}$ & $256 \mathrm{ab}$ \\
Propagation method & & & $P=0.0008$ & $P=0.0014$ \\
& Cutting & 30 & $7.48 \mathrm{a}$ & $269 \mathrm{a}$ \\
& TC (A) & 30 & $4.49 \mathrm{~b}$ & $261 \mathrm{a}$ \\
Rootstock $\times$ propagation method & Seed & 30 & $3.02 \mathrm{c}$ & $255 \mathrm{a}$ \\
\hline
\end{tabular}

Different letters within columns indicate significant differences according to Tukey's HSD test $(P<0.05)$. $\mathrm{N}$, number of plants.

Table 5. Number of primary roots and first order lateral roots, total root length (TRL), and specific root length (SRL) of seven rootstocks propagated by seed, cutting, or tissue culture (TC).

\begin{tabular}{|c|c|c|c|c|c|}
\hline Rootstock & Seed & Stem cutting & $\mathrm{TC}(\mathrm{A})$ & $\mathrm{TC}(\mathrm{B})$ & $P$ value \\
\hline \multicolumn{6}{|c|}{ Number of primary roots } \\
\hline Cleopatra & $1.0 \mathrm{~b}$ & $6.5 \mathrm{a}$ & - & - & 0.0019 \\
\hline US-802 & $1.0 \mathrm{c}$ & $7.3 \mathrm{a}$ & $5.3 \mathrm{ab}$ & $4.3 \mathrm{abc}$ & 0.0013 \\
\hline US-812 & $1.2 \mathrm{~b}$ & $9.7 \mathrm{a}$ & $3.7 \mathrm{ab}$ & - & 0.0005 \\
\hline US-897 & $1.0 \mathrm{c}$ & $9.3 \mathrm{a}$ & $2.8 \mathrm{~b}$ & $2.3 \mathrm{~b}$ & 0.0010 \\
\hline US-942 & $1.2 \mathrm{~b}$ & $8.2 \mathrm{a}$ & $6.3 \mathrm{a}$ & - & 0.0002 \\
\hline Swingle & $1.2 \mathrm{~b}$ & $8.7 \mathrm{a}$ & $3.3 \mathrm{~b}$ & - & $<0.0001$ \\
\hline X-639 & $1.0 \mathrm{~b}$ & - & $2.5 \mathrm{ab}$ & $3.2 \mathrm{a}$ & 0.0039 \\
\hline \multicolumn{6}{|c|}{ Number of first order lateral roots } \\
\hline Cleopatra & $55.0 \mathrm{~b}$ & $108.3 \mathrm{a}$ & - & - & 0.0007 \\
\hline US-802 & $42.5 \mathrm{c}$ & $124.2 \mathrm{a}$ & $102.5 \mathrm{a}$ & $88.5 \mathrm{ab}$ & 0.0007 \\
\hline US-812 & $67.5 \mathrm{~b}$ & $128.5 \mathrm{a}$ & $83.2 \mathrm{~b}$ & - & 0.0002 \\
\hline US-897 & $62.0 \mathrm{~b}$ & $184.8 \mathrm{a}$ & $68.0 \mathrm{~b}$ & $71.8 \mathrm{~b}$ & 0.0017 \\
\hline US-942 & $78.0 \mathrm{~b}$ & $133.5 \mathrm{a}$ & $92.2 \mathrm{~b}$ & - & 0.0002 \\
\hline Swingle & $61.5 \mathrm{~b}$ & $117.0 \mathrm{a}$ & $65.8 \mathrm{~b}$ & - & $<0.0001$ \\
\hline X-639 & $55.2 \mathrm{a}$ & - & $53.3 \mathrm{a}$ & $87.8 \mathrm{a}$ & 0.0530 \\
\hline \multicolumn{6}{|c|}{$T R L(m)$} \\
\hline Cleopatra & $2.6 \mathrm{~b}$ & $4.9 \mathrm{a}$ & - & - & 0.0004 \\
\hline US-802 & $4.0 \mathrm{a}$ & $3.3 \mathrm{a}$ & $3.5 \mathrm{a}$ & $3.1 \mathrm{a}$ & 0.3760 \\
\hline US-812 & $3.2 \mathrm{a}$ & $3.3 \mathrm{a}$ & $2.9 \mathrm{a}$ & - & 0.5924 \\
\hline US-897 & $3.3 \mathrm{a}$ & $4.2 \mathrm{a}$ & $2.9 \mathrm{a}$ & $2.9 \mathrm{a}$ & 0.0482 \\
\hline US-942 & $3.5 \mathrm{a}$ & $3.3 \mathrm{a}$ & $2.9 \mathrm{a}$ & - & 0.1261 \\
\hline Swingle & $5.1 \mathrm{a}$ & $2.8 \mathrm{~b}$ & $4.6 \mathrm{a}$ & - & 0.0007 \\
\hline X-639 & $2.3 \mathrm{~b}$ & - & $2.3 \mathrm{~b}$ & $5.0 \mathrm{a}$ & $<0.0001$ \\
\hline \multicolumn{6}{|c|}{$S R L\left(m \cdot g^{-1}\right)$} \\
\hline Cleopatra & $7.3 \mathrm{~b}$ & $23.0 \mathrm{a}$ & - & - & $<0.0001$ \\
\hline US-802 & $19.9 \mathrm{ab}$ & $27.9 \mathrm{a}$ & $21.1 \mathrm{ab}$ & $15.6 \mathrm{~b}$ & 0.0038 \\
\hline US-812 & $12.9 \mathrm{~b}$ & $33.1 \mathrm{a}$ & $18.8 \mathrm{~b}$ & - & $<0.0001$ \\
\hline US-897 & $15.1 \mathrm{c}$ & $43.1 \mathrm{a}$ & $24.2 \mathrm{~b}$ & $10.2 \mathrm{c}$ & $<0.0001$ \\
\hline US-942 & $15.7 \mathrm{~b}$ & $43.1 \mathrm{a}$ & $23.4 \mathrm{ab}$ & - & 0.0005 \\
\hline Swingle & $10.0 \mathrm{c}$ & $21.2 \mathrm{a}$ & $15.0 \mathrm{~b}$ & - & $<0.0001$ \\
\hline X-639 & $13.0 \mathrm{ab}$ & - & $22.6 \mathrm{a}$ & $10.9 \mathrm{~b}$ & 0.0027 \\
\hline
\end{tabular}

Different letters within rows for each rootstock indicate significant differences according to Tukey's HSD test or Dunn's multiple comparison test $(P<0.05)$. 
Shoot to root ratio $(S / R)$. In all seven rootstocks, the shoot to root ratio differed significantly $(P<0.03)$ between plants propagated through different methods (Table 3 ). The highest ratio was found in plants propagated by cuttings $(5.2-8.6)$ whereas the lowest ratio was found for plants propagated from seed (2.4-3.8). For seedlings, 'US-802' and ' $\mathrm{X}-639$ ' had highest shoot to root ratio (3.8) and 'Swingle' the lowest (2.4). For cuttings, shoot to root ratio was highest in 'US-897' and 'US-942' (8.5-8.6) and lowest in 'Cleopatra' (5.2). Shoot to root ratio of plants generated from TC method A ranged from 4.2 ('US-812') to 6.6 ('X-639') whereas TC method B produced plants with a ratio of 2.5-2.7 ('US-897' and 'X-639') and 4.9 ('US-802').

Factorial analysis of the rootstock cultivars 'US-802', 'US-812', 'US-897', 'US942', and 'Swingle' propagated through seed, stem cutting, or TC method A showed no significant $(P=0.0777)$ interaction of rootstock and propagation method for shoot to root ratio (Table 4). Significant differences were observed among rootstocks, with 'US897' and 'US-942' having the highest shoot to root ratio (5.6) and 'Swingle' the lowest (4.2). Plants propagated by cuttings had a significantly higher shoot to root ratio (7.5) compared with plants originating from TC (4.5) or from seed (3.0).

$S L A$. The SLA differed significantly between plants propagated by seed, cuttings, and TC in all rootstocks except 'US-812' and 'US-942'. Plants propagated by TC method B had a significantly lower SLA (154-234 $\mathrm{cm}^{2} \cdot \mathrm{g}^{-1}$ ) compared with plants propagated through all other methods, which measured $233-281 \mathrm{~cm}^{2} \cdot \mathrm{g}^{-1}$. For most rootstocks, no significant differences were measured between plants propagated by seedling, cutting, or TC method A. Only 'Cleopatra' and 'Swingle' had a significantly lower SLA when grown from seed compared with cuttings. Among rootstock seedlings, 'US-812' had the highest SLA $\left(278 \mathrm{~cm}^{2} \cdot \mathrm{g}^{-1}\right)$ and 'Cleopatra' the lowest $\left(183 \mathrm{~cm}^{2} \cdot \mathrm{g}^{-1}\right)$. SLA of cuttings ranged from $206 \mathrm{~cm}^{2} \cdot \mathrm{g}^{-1}$ for 'Cleopatra' to $281 \mathrm{~cm}^{2} \cdot \mathrm{g}^{-1}$ for 'US-942', which is similar to SLA of TC propagated plants (method A) which ranged from 243 $\mathrm{cm}^{2} \cdot \mathrm{g}^{-1}$ for 'US-897' to $274 \mathrm{~cm}^{2} \cdot \mathrm{g}^{-1}$ for 'US802 '.

Factorial analysis of the rootstock cultivars 'US-802', 'US-812', 'US-897', 'US942', and 'Swingle' propagated through seed, stem cutting, or TC method A showed no significant interaction between rootstock and propagation method $(P=0.2003)$. Whereas no significant differences were found based on propagation method $(P=0.0855)$, SLA varied significantly $(P=0.0014)$ depending on the rootstock. SLA was highest for 'US942' and 'US-802' (271-273 $\left.\mathrm{cm}^{2} \cdot \mathrm{g}^{-1}\right)$ and lowest for 'US-897' $\left(242 \mathrm{~cm}^{2} \cdot \mathrm{g}^{-1}\right)$.

Root architecture. The number of primary roots differed significantly between propagation methods for all seven rootstocks (Table 5). For all rootstocks, the largest number of primary roots was observed for cuttings and ranged from 6.5 ('Cleopatra') to 9.7 ('US-812'). Most of the plants grown from seed developed one taproot. For plants from TC, the number of primary roots ranged from 2.3 for 'US-897' to 6.3 for 'US-942'.

The number of first order lateral roots differed significantly between propagation methods for all rootstock, except 'X-639'. Largest numbers were found for all rootstocks grown from cuttings and ranged from 108 for 'Cleopatra' to 185 for 'US-897'. The number of lateral roots for plants generated from TC ranged from 53 ('X-639') to 103
('US-802') for method A and from 72 to 88 for method B. Rootstock seedlings had the lowest number of lateral roots, which ranged from 43 for 'US-802' to 78 for 'US-942'.

The TRL of plants ranged from $2.3 \mathrm{~m}$ to $5.1 \mathrm{~m}$ and varied significantly depending on the propagation method for the rootstocks 'Cleopatra', 'US-897', 'Swingle', and 'X639'. The SRL, expressed as the ratio of TRL and dry weight of roots, was significantly different between plants propagated by seed, cuttings, and TC in all seven rootstocks and was highest in plants grown
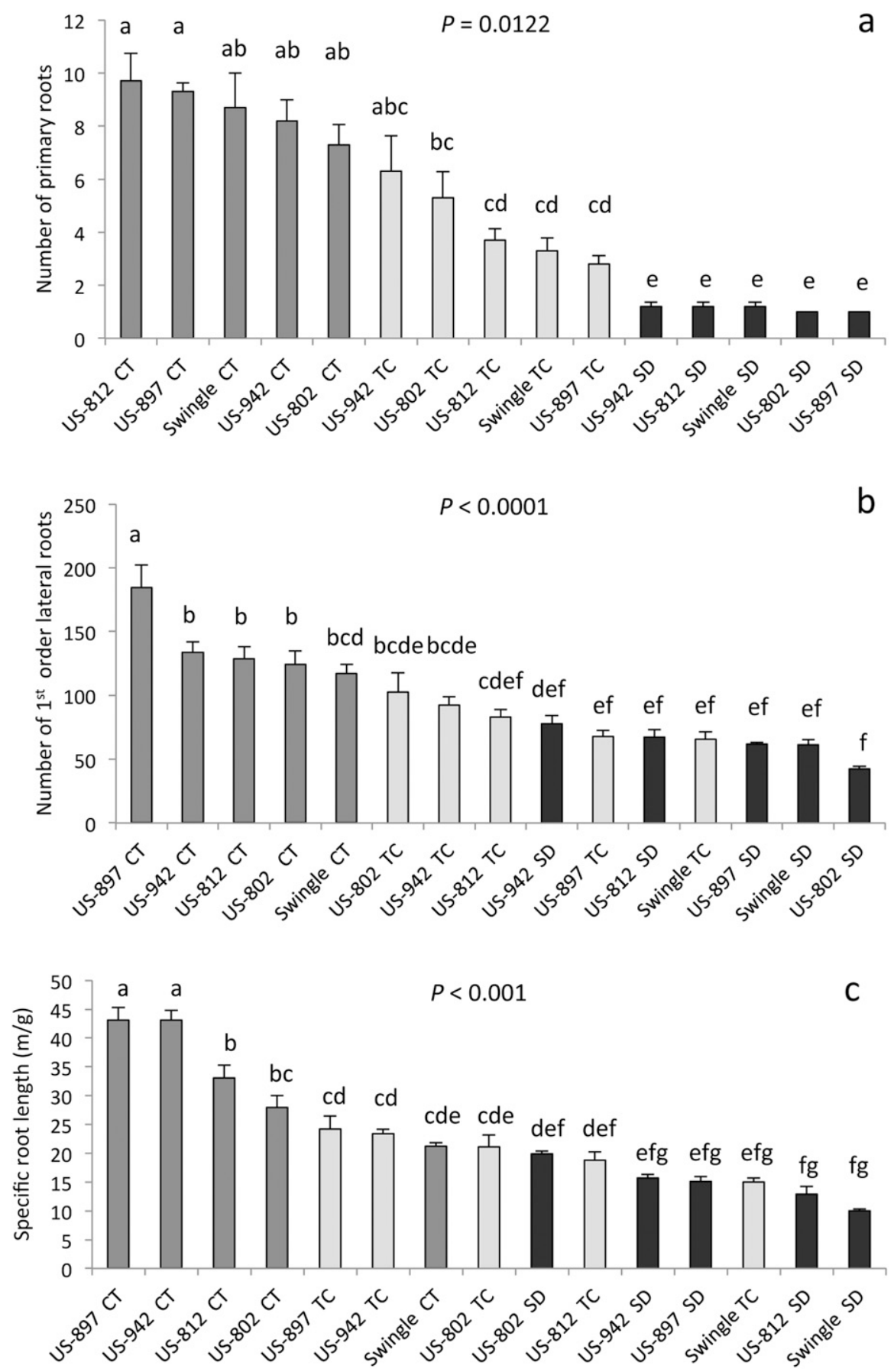

Fig. 2. Number of primary roots (A), and number of first order lateral roots (B), and specific root length (C) of five rootstocks propagated by seed (black bars), cutting (gray bars), and tissue culture (TC) (light gray bars). Plants from TC were propagated by method A. 
from cuttings $\left(21.2-43.1 \mathrm{~m} \cdot \mathrm{g}^{-1}\right)$. Among rootstock seedlings, 'US-802' had the highest SRL (19.9 $\left.\mathrm{m} \cdot \mathrm{g}^{-1}\right)$ and 'Cleopatra' the lowest $\left(7.3 \mathrm{~m} \cdot \mathrm{g}^{-1}\right)$. Among cuttings, highest SRL was found for 'US-897' and 'US-942' $\left(43.1 \mathrm{~m} \cdot \mathrm{g}^{-1}\right)$ and lowest for 'Swingle' $\left(21.2 \mathrm{~m} \cdot \mathrm{g}^{-1}\right)$. TC method A resulted in plants with a SRL ranging from $15.0 \mathrm{~m} \cdot \mathrm{g}^{-1}$ ('Swingle') to $24.2 \mathrm{~m} \cdot \mathrm{g}^{-1}$ for 'US-897'. Plants generated from TC method B ranged from 10.2 to $15.6 \mathrm{~m} \cdot \mathrm{g}^{-1}$ in SRL.

Factorial analysis of 'US-802', 'US-812', 'US-897', 'US-942', and 'Swingle' plants generated from seed, stem cutting, or TC method A found significant interactions between rootstock and propagation method for the number of primary roots $(P=0.0122)$ and first order lateral roots $(P<0.0001)$. Despite the interaction, all plants propagated through cuttings had a larger number of primary (adventitious) roots than plants generated by TC method A or by seed (Fig. 2A). Similarly, the number of lateral roots was largest in all plants derived from cuttings whereas most of the plants propagated from seeds were amongst the plants with the lowest number (Fig. 2B). A significant $(P<$ $0.0001)$ interaction for rootstock and propagation method was also found for TRL ( $P=$ $0.0003)$ and SRL $(P<0.0001)$. Highest TRL $(5.1 \mathrm{~m})$ was measured for 'Swingle' seedlings, and lowest for 'US-897', 'US-942', and 'US-812' from TC and 'Swingle' cuttings (2.8-2.9 m). By contrast, 'US-897' and 'US942' cuttings exhibited the highest SRL (43.1 $\mathrm{m} \cdot \mathrm{g}^{-1}$ ) whereas 'Swingle' seedlings exhibited the lowest SRL $\left(10.0 \mathrm{~m} \cdot \mathrm{g}^{-1}\right)$. SRL for the five different rootstock/propagation method combinations are depicted in Fig. 2C. Despite the interaction, four of the five rootstocks propagated by cuttings had the highest SRL whereas most of the plants propagated by seed were amongst the ones with the lowest SRL. SRL was positively correlated with the number of primary roots $(R=0.718)$ and the number of lateral roots $(R=0.621)$.

Figure 3 shows the typical root system of three citrus plants propagated by seed, cutting, and TC.

\section{Discussion}

Despite the prevalence of micropropagation in many woody tree production systems, particularly forest trees, but also many fruit tree crops, commercial citrus propagation still relies mainly on propagation from seed. However, for most of the desired varieties, seed sources are inadequate to meet the demands. As a consequence, nurseries have to rely on rootstocks that are derived through vegetative propagation, namely, cuttings and TC. Although there are many anecdotal reports about the inferiority of citrus plants derived through vegetative propagation, no systematic study has yet been conducted. The present study provides information on the traits of seven of the top ten citrus rootstocks in Florida (Budwood Annual Report 201516) propagated by seed, stem cuttings, and $\mathrm{TC}$, during the early weeks of growth under nursery conditions.

Analysis of biomass distribution revealed considerable differences depending on the rootstock and on the type of propagation. Despite the interaction of rootstock and propagation method, a general trend was observed indicating a larger root mass fraction for plants derived from seed compared with micropropagated plants and stem cuttings. In accordance with these observations, the lowest shoot to root ratio was found for seedlings and the highest ratio was found for cuttings. Field observations of citrus trees conducted in the 1950s reported shallower and sparser root systems of cuttings compared with seedlings (Savage et al., 1945;
Halma, 1947), resulting in a general acceptance of cuttings as inferior to seedlings. However, these studies were conducted with the purpose of comparing scion cuttings with grafted trees and did not include comparisons of rootstocks. Studies investigating the biomass partitioning response of different plant systems to nutrient supply discovered a positive linear relationship between shoot to root ratio and the internal nutrient status of plants (Cambui et al., 2011). Therefore, it is possible that the lower relative root mass and concordant higher shoot to root ratio of plants generated by TC and stem cuttings is the result of a higher efficiency of their root system. However, influence of different nutrient exposure and other factors associated with the propagation technique, particularly differences in growing time, cannot be excluded. It is also unclear whether plant partitioning observed under nursery conditions will persist under field conditions and in a grafted citrus tree. Poorter et al. (2012) suggested that as trees mature they will increasingly invest more resources in support tissues and that biomass allocation of greenhouse grown young seedlings is likely to change under field conditions. Despite predicted changes in the biomass distribution based on plant development, nutrient availability, and other factors, it is expected that differences in biomass partitioning in differently propagated plants will persist at least during the early stages of establishment in the field.

The SLA of a plant is defined as the onesided area of a fresh leaf, divided by its ovendry weight and is closely correlated with the relative growth rate of a plant (Ruíz-Robleto and Villar, 2005). Because SLA reflects the expected return on previously captured resources, high SLA leaves are generally considered productive (Wilson et al., 1999).
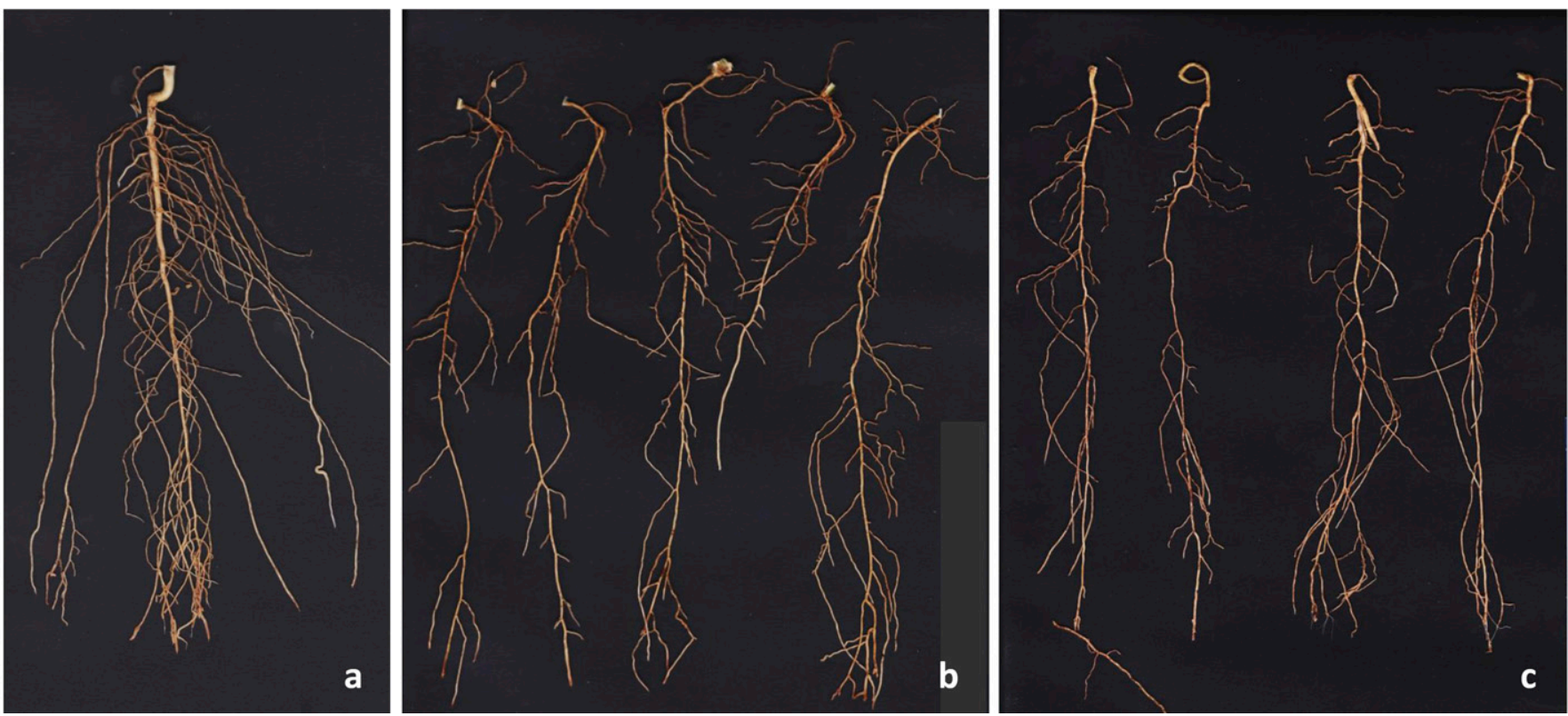

Fig. 3. Typical root systems of three 'US-802' plants propagated by seed (A), cutting (B), and tissue culture (C). Adventitious roots shown in (B) and (C) were excised from the plant base. 
Warrag et al. (1989a) observed a higher growth rate and net photosynthesis of Eucalyptus grandis seedlings compared with tissue culture plants during the early stages of development, but differences decreased sharply within few months of continuous growth in the greenhouse. No advantage was found in terms of dry weight accumulation and distribution for seedlings or TC plants (Warrag et al., 1989b). In the present study, we did not compare growth rates of rootstock plants. However, our results demonstrate significant differences of SLA among the different rootstocks, which were mostly independent of the propagation method. No differences in SLA were observed among plants of the same rootstock propagated by TC method A, by cuttings and by seed, but SLA of plants from TC method B was considerably lower. It is likely that reduced lighting and consequently, reduced photosynthesis during the early stages of plant acclimatization in the greenhouse tunnel is responsible for the reduced SLA of plants propagated with this procedure. Whether rootstock or propagation method influences SLA in grafted citrus trees remains to be investigated.

The root architecture varied significantly among rootstocks and propagation type, and significant interactions were observed for all variables measured. Despite the interaction of rootstock and propagation method, there was a trend for the largest number of primary roots, lateral roots, and SRL in rooted cuttings and the lowest number of all three variables in seedlings. Not surprisingly, plants grown from seed generally had only one well-defined primary (tap) root whereas the number of primary roots in plants derived from cuttings ranged from 6 to 10 and from 3 to 6 in plants from TC. In a study by Palma et al. (1997), multiple (3-4) adventitious roots with a larger overall length were counted in Citrus macrophylla plants from rooted microcuttings compared with seedlings which were of a typical pivotant root type. They concluded that the in vitroformed adventitious roots would be more efficient for nutrient uptake than the single perpendicular root of the seedlings. Bell et al. (1993) reported multiple adventitious roots in E. camaldulensis plants produced by micropropagation, which developed into six to nine spreading roots during the first nine months of growth in the field. No architectural differences, above- or below-ground were observed between seedlings and micropropagated plants whereas large variations were observed between genotypes.

The SRL of a plant provides a ratio of a standard unit of acquisition (root length) to resource investment (mass) (Pérez-Harguindeguy et al., 2013). Plants with high SRL build more root length for a given dry-weight investment and are generally considered to have higher rates of nutrient and water uptake, shorter root lifespan, and higher relative growth rates than for low SRL plants. Ostonen et al. (2007) suggested that SRL may be used as an indicator of nutrient availability to plants in experimental conditions. We found that within all citrus rootstocks, SRL differed significantly depending on the propagation method. SRL was positively correlated with the number of primary and lateral roots, and despite a significant rootstock $\times$ propagation method interaction, a general trend was observed for the highest SRL in plants from cuttings and the lowest SRL in seedlings. No such trend was observed for the TRL. Eissenstat (1991) studied the root structure of citrus trees on different rootstocks under field conditions. He suggested that plants with high SRL may be more successful in the competition for limited soil resources and that production of high SRL roots may be a characteristic of "opportunistic" root growth. The higher SRL found for cuttings and most TCpropagated plants in the present study suggests that citrus rootstocks propagated by vegetative methods may be more efficient in their ability to uptake nutrients and water compared with plants grown from seed. This is supported by the observations of Castle and Youtsey (1977) who evaluated root systems of rooted 'Valencia' cuttings in comparison with trees propagated on 12 rootstocks in nursery trees. They found that cuttings exhibited a root system mostly composed of fibrous roots and rapidly increased in size after planting. Early studies by Halma (1931) did not find any indications that citrus trees grown from cuttings are inferior to budded trees in the nursery. In the woody plant Jatropha curcas, plants from auxin-treated stem cuttings were observed to grow faster and to produce more fruit in the first year than plants from seed (Kochhar et al., 2008). No difference was found between seedlings and untreated cuttings.

Despite the apparent positive association of SRL with resource acquisition, Eissenstat (1991) pointed out that construction of roots with a high SRL is associated with substantial cost. Interestingly, Basile et al. (2007) reported evidence that in peach trees, dwarfing rootstocks produce a larger amount of fine roots per unit canopy size than more vigorous rootstocks. He suggested that a greater allocation of carbohydrates to the size-controlling rootstocks may limit carbon allocation to the shoots, thereby restricting growth. The same trend does not seem to be true for the high SRL rootstock cuttings and TC plants in the present study as these plants were found to have considerably higher biomass allocated to the aboveground portion of the plant than lowerSRL rootstock seedlings.

In conclusion, many differences in plant traits were observed in seven different citrus rootstocks propagated by seed, stem cuttings, and TC, and many of the traits were influenced by propagation method as well as rootstock genotype. Based on the observed higher allocation of biomass to the aboveground portion of the plants in combination with the greater abundance of primary and lateral roots and larger SRL, it is suggested that rootstocks propagated by cuttings and TC may be superior in regard to resource acquisition compared with rootstocks derived from seedlings, and therefore, favorable for citrus tree performance during the early growth stage.

\section{Literature Cited}

Albrecht, U. and K.D. Bowman. 2011. Tolerance of the trifoliate citrus hybrid 'US-897' (Citrus reticulata Blanco $\times$ Poncirus trifoliata $\mathrm{L}$. Raf.) to huanglongbing. HortScience 46:16-22.

Albrecht, U. and K.D. Bowman. 2012. Tolerance of trifoliate citrus rootstock hybrids to Candidatus Liberibacter asiaticus. Sci. Hort. 147:71-80.

Anderson, J.M. and J.S.I. Ingram. 1993. Tropical soil biology and fertility: A handbook of methods. $\mathrm{CAB}$ International, Wallingford, UK, University of Arizona Press, Tuscon, AZ.

Asaah, E.K., T.N. Wanduku, Z. Tchoundjeu, L. Kouodiekong, and P. Van Damme. 2012. Do propagation methods affect the fine root architecture of African plum (Dacryodes edulis)? Trees 26:1461-1469.

Basile, B., D.R. Bryla, M.L. Salsman, J. Marsal, C. Cirillo, R.S. Johnson, and T.M. Dejong. 2007. Growth patterns and morphology of fine roots of size-controlling and invigorating peach rootstocks. Tree Physiol. 27:231-241.

Bell, D.T., P.G. van der Moezel, I.J. Bennett, J.A. McComb, C.F. Wilkins, S.C.B. Marshall, and A.L. Morgan. 1993. Comparison of growth of Eucalyptus camaldulensis from seeds and tissue culture: Root, shoot and leaf morphology of 9-month-old plants grown in deep sand and sand over clay. For. Ecol. Mgt. 57:125-139.

Bowman, K.D. and U. Albrecht. 2017. Efficient propagation of citrus rootstocks by stem cuttings. Sci. Hort. 225:681-688.

Bowman, K.D., H.K. Wutscher, R.D. Hartman, and A.E. Lamb. 1997. Enhancing development of improved rootstocks by tissue culture propagation and field performance of selected rootstocks. Proc. Annu. Meet. Fla. State Hort. Soc. 110:10-13.

Bowman, K.D., G. McCollum, and U. Albrecht. 2016a. Performance of 'Valencia' orange (Citrus sinensis [L.] Osbeck) on 17 rootstocks in a trial severely affected by huanglongbing. Sci. Hort. 201:355-361.

Bowman, K.D., L. Faulkner, and M. Kesinger. 2016b. New citrus rootstocks released by USDA 2001-2010: Field performance and nursery characteristics. HortScience 51:12081214

Cambui, C.A., H. Svennerstam, L. Gruffman, A Nordi, U. Ganeteg, and T. Näsholm. 2011. Patterns of plant biomass partitioning depend on nitrogen source. PLoS One 6(4):E19211.

Castle, W.S. 2010. A career perspective on citrus rootstocks, their development, and commercialization. HortScience 45:11-15.

Castle, W.S. and C.O. Youtsey. 1977. Root system characteristics of citrus nursery trees. Proc. Annu. Meet. Fla. State Hort. Soc. 90:39-44.

Chaires, P. 2017. Citrus nurseries analyze the need for seed. Florida Grower, Feb. 2017. Citrus Budwood Annual Report 2016-17. <http:// www.freshfromflorida.com/content/download/ 72969/1974302/2015-2016_Annual_Report_ Final.pdf>.

Eissenstat, D.M. 1991. On the relationship between specific root length and the rate of root proliferation: A field study using citrus rootstocks. New Phytol. 118:63-68.

Folimonova, S.Y., C.J. Robertson, S.M. Garnsey, S. Gowda, and W.O. Dawson. 2009. Examination of the responses of different genotypes of citrus to huanglongbing (citrus greening) under different conditions. Phytopathology 99:13461354

Johnson, E.G., J. Wu, D.B. Bright, and J.H. Graham. 2014. Association of 'Candidatus Liberibacter asiaticus' root infection, but not phloem plugging with root loss on huanglongbing-affected 
trees prior to appearance of foliar symptoms. Plant Pathol. 63:290-298.

Halma, F.F. 1931. The propagation of citrus by cuttings. Hilgardia 6:131-157.

Halma, F.F. 1947. Own-rooted and budded lemon trees. Calif. Citrog. 33:2, 3, 14, 15.

Kochhar, S., S.P. Singh, and V.K. Kochhar. 2008. Effects of auxins and associated biochemical changes during clonal propagation of the biofuel plant - Jatropha curcas. Biomass Bioenergy 32:1136-1143.

Murashige, T. and F. Skoog. 1962. A revised medium for rapid growth and bio assays with tobacco tissue cultures. Physiol. Plant. 15:473497.

Ostonen, I., Ü. Püttsepp, C. Biel, O. Alberton, M.R. Bakker, H. Lõhmus, D. Majdi, D. Metcalfe, A.F.M. Olsthoorn, A. Pronk, E. Vanguelova, M. Weih, and I. Brunner. 2007. Specific root length as an indicator of environmental change. Plant Biosyst. 141:426-442.

Palma, B., H. Bravo, and M. Castro. 1997. Comparative study of root systems in Citrus macrophylla seedlings and microcuttings propagated in vitro. Acta Hort. 447:591596.

Pérez-Harguindeguy, N., S. Díaz, E. Garnier, S. Lavorel, H. Poorter, P. Jaureguiberry, M.S. Bret-Harte, W.K. Cornwell, J.M. Craine, D.E. Gurvich, C. Urcelay, E.J. Veneklaas, P.B. Reich, L. Poorter, I.J. Wright, P. Ray, L. Enrico, J.G. Pausas, A.C. de Vos, N. Buchmann, G. Funes, F. Quétier, J.G. Hodgson, K. Thompson, H.D. Morgan, H. ter Steege, M.G.A. van der Heijden, L. Sack, B. Blonder, P. Poschlod, M.V. Vaieretti, G. Conti, A.C. Staver, S. Aquino, and J.H.C. Cornelissen. 2013. New handbook for standardized measurement of plant functional traits worldwide. Austral. J. Bot. 61:167234.

Poorter, H., K.J. Niklas, P.B. Reich, J. Oleksyn, P. Poot, and L. Mommer. 2012. Biomass allocation to leaves, stems and roots: Meta-analyses of interspecific variation and environmental control. New Phytol. 193:30-50.

Ruíz-Robleto, J. and R. Villar. 2005. Relative growth rate and biomass allocation in ten woody species with different leaf longevity using phylogenetic independent contrasts (PICs). Plant Biol. 7:484-494.

Savage, E.M., W.C. Cooper, and R.B. Piper. 1945. Root systems of various citrus rootstocks. Proc. Annu. Meet. Fla. State Hort. Soc. 58:44-48.

Warrag, E., M.S. Lesney, and D.L. Rockwood. 1989a. Comparative greenhouse study of Eucalyptus grandis in vitro plantlets and half-sib seedlings, I. Net photosynthesis. Plant Cell Rep. 8:497-499.

Warrag, E., M.S. Lesney, and D.L. Rockwood. 1989b. Comparative greenhouse study of Eucalyptus grandis in vitro plantlets and half-sib seedlings, II. Dry matter accumulation and relative distribution. Plant Cell Rep. 8:500503.

Webber, H.J., W. Reuther, and H.W. Lawton. 1967. History and development of the citrus industry, p. 1-39. In: W. Reuther (ed.). The citrus industry, University of California, Berkeley, CA.

Wilson, P.J., K. Thompson, and J.G. Hodgson. 1999. Specific leaf area and leaf dry matter content as alternative predictors of plant strategies. New Phytol. 143:155-162. 